\title{
Severe anemia in late pregnancy: a retrospective study at a tertiary care rural medical college in Gujarat, India
}

\author{
Shilpa A. Sapre*, Nitin S. Raithatha, Rumi S. Bhattacharjee
}

Department of Obstetrics and Gynecology, Pramukhswami Medical College Karamsad, Gujarat, India

Received: 11 January 2018

Accepted: 10 February 2018

\section{*Correspondence:}

Dr. Shilpa A. Sapre,

E-mail: shilpasapre14@gmail.com

Copyright: ( $)$ the author(s), publisher and licensee Medip Academy. This is an open-access article distributed under the terms of the Creative Commons Attribution Non-Commercial License, which permits unrestricted non-commercial use, distribution, and reproduction in any medium, provided the original work is properly cited.

\begin{abstract}
Background: Anaemia in pregnancy is the commonest medical disorder in developing countries like India. It has multifactorial etiology and is associated with increased maternal and perinatal morbidity and mortality. The study aimed at analyzing the socio-demographic variables and also the maternal and perinatal outcome of pregnant women admitted to labour room with severe anaemia $(\mathrm{Hb}<7 \mathrm{gm} \%)$ late in pregnancy.

Methods: This is a retrospective observational study done at a tertiary care rural medical college in Gujarat over a 3 year period from January 2014 to December 2016.

Results: Results of the study were analyzed. Out of 3963 deliveries during the study period 225 (5.6\%) patients were severely anaemic. There were $177(78.6 \%)$ unbooked patients and $169(75.1 \%)$ were multigravidas. Majority of patients belonged to under $24 \mathrm{yr}$ age group. Maternal complications were in form of preterm labour (44\%), preeclampsia-ecclampsia $(24.8 \%)$, cardiac failure $(2.2 \%)$, PPH $(2.2 \%)$ maternal death $(0.4 \%)$. Neonatal outcome was analyzed in terms of prematurity (44\%), LBW (24.8\%), NICU admission (15.1\%), still birth (4.4\%), neonatal death $(11.5 \%)$.

Conclusions: Severe anaemia during pregnancy is associated with adverse maternal and perinatal outcome. It is also one of the preventable indirect cause of maternal mortality. Imparting health education to adolescent girls, regular antenatal check-ups, early diagnosis and treatment along with active participation of ASHA workers at grass-root level might help in bringing down the prevalence. A more focused approach is warranted towards pregnant women in rural and underdeveloped areas of India.
\end{abstract}

Keywords: Late pregnancy, Maternal outcome, Perinatal outcome, Rural area, Severe anemia

\section{INTRODUCTION}

Anaemia is the leading cause of maternal morbidity and mortality in developing countries. ${ }^{1}$ It also has a significant impact on the fetus leading to low birth weight and increased perinatal morbidity and mortality. Nutritional anemia is the most common cause of anaemia in pregnancy. $^{2}$ The prevalence of anaemia during pregnancy is $18 \%$ in developed countries as against $56 \%$ in developing nations. ${ }^{3,4}$ The prevalence of anemia during pregnancy in India is $87 \%$ which is quite high. ${ }^{5-7}$ A lot of work is being done in the control and prevention of anemia at local and national level but there is little progress in bringing down the prevalence of anemia. There are many studies in India on anemia in pregnancy but very few studies have focused on the prevalence of severe anemia in rural areas. ${ }^{8-13}$ Ghimire and Ghimire from Nepal have found co-relation between severe anemia and poor perinatal outcome. ${ }^{14}$ In addition studies by Brabin et al and Ali et al have found a strong association of severe anemia in pregnancy with maternal 
mortality and higher prevalence of pre-eclampsia respectively. ${ }^{15,16}$

World Health Organization defines anemia as haemoglobin less than $11 \mathrm{gm} / \mathrm{dl}$ in $1^{\text {st }}$ and $3^{\text {rd }}$ trimester and less than $10.5 \mathrm{gm} / \mathrm{dl}$ in $2^{\text {nd }}$ trimester.

Anaemia is further classified into mild, moderate and severe by ICMR depending upon the levels of hemoglobin.

- $\quad$ Mild: $\mathrm{Hb} \%$ 10-10.9gm\%

- Moderate: $\mathrm{Hb} \%$ 7-10 gm\%

- Severe: $\mathrm{Hb} \%$ 4-7 gm\%

- Very severe: less than $4 \mathrm{gm} \%$.

Anaemia has multifactorial etiology. ${ }^{17}$ Nutritional anemia is more common in pregnancy. Socio-demographic factors faulty dietary habits, increased iron demand, low immunity, compounded by physiological changes of pregnancy contribute to anemia in pregnancy. ${ }^{18,19}$ In rural areas social and socio-demographic factors predominantly contribute to anemia.

Anaemic women presenting at the time of labour is a challenge for the treating obstetrician because even a little blood loss at the time of delivery might prove life threatening. Moreover, if it is diagnosed early in pregnancy corrective measures can be taken.

\section{METHODS}

This is a Retrospective observational study done at Pramukhswami Medical college, Karamsad, Gujarat over a 3-year period from January 2014-December 2016. Pramukhswami medical college is a tertiary care rural medical college in Karamsad, Gujarat. It has a 600 bedded Shri Krishna hospital which caters to the needs of the rural population.

\section{Inclusion criteria}

Women with singleton pregnancy having severe anaemia $(\mathrm{Hb} \%<7 \mathrm{gm} \%)$ admitted in labour in late pregnancy during 3 year period (January 2014- December 2016).

\section{Exclusion criteria}

Pregnant women with hemolytic anaemia were excluded from the study. Pregnant women with severe anaemia due to acute blood loss (APH) were excluded from the study. Pregnant women with medical disorders like hypertension, diabetes, cardiac disease were excluded.

Medical records of patients fulfilling the inclusion criteria were studied for maternal age, parity, booking status, gestational age, preeclampsia, LBW, prematurity, NICU admission, fetal demise, PPH, maternal Intensive care, and maternal mortality.

\section{Statistical analysis}

Data collected was arranged in MS Excel sheet. Statistical analysis was done using percentage, mean and median. Conclusions were drawn on same.

\section{RESULTS}

There were 3963 deliveries during the 3 year study period. Out of these 225 patients had severe anaemia. The hemoglobin level in the study group ranges from $1.9 \%$ $6.9 \% .197(87.5 \%)$ patients had hemoglobin in the range of 4-7 gm\% followed by $28(12.4 \%)$ patients with hemoglobin less than $4 \mathrm{gm} \%$.

Table 1: Patient characteristics.

\begin{tabular}{|l|l|}
\hline Hb\% & No. of patients \\
\hline $4-7$ gm\% & $197(87.5 \%)$ \\
\hline$<4$ gm\% & $28(12.4 \%)$ \\
\hline Age group & $103(45.7 \%)$ \\
\hline$<24$ & $76(33.7 \%)$ \\
\hline $25-29$ & $46(20.4 \%)$ \\
\hline 30 and above & \\
\hline Booking status & $48(21.3 \%)$ \\
\hline Booked & $177(78.6 \%)$ \\
\hline Unbooked & $126(56 \%)$ \\
\hline Gestational status & $58(25.7 \%)$ \\
\hline $37-42$ wks & $41(18.2 \%)$ \\
\hline $34-37$ wks & \\
\hline$<34$ wks & $58(25.7 \%)$ \\
\hline Gravida & $156(69.3 \%)$ \\
\hline 1 & $11(4.8 \%)$ \\
\hline $2-5$ & \\
\hline 5 and above & \\
\hline
\end{tabular}

Out of these 225 cases, $103(45.7 \%)$ patients were below the age group of 24 years followed by 76 (33.7\%) patients in the age group of 25-29 years and 46 (20.4\%) patients were above 30 years of age.

177 (78.6\%) patients were unbooked as against 48 $(21.3 \%)$ who were booked. In the study there were 167 (74.2\%) multigravidas as against 58 (25.7\%) patients who were primigravida.

Table 2: Obstetric outcomes.

\begin{tabular}{|ll|}
\hline Mode of delivery & \\
\hline Vaginal & 163 \\
\hline LSCS & 62 \\
\hline
\end{tabular}

Out of 225 patients $126(56 \%)$ women had presented in labour at term followed by $58(25.7 \%)$ women in the gestational age group of 34-37 weeks, 41 (18.2\%) women presented at less than 34 weeks of gestation. 
Table 3: Maternal complications.

\begin{tabular}{|l|l|}
\hline Pre-term labour & $99(44 \%)$ \\
\hline IUGR & $56(24.8 \%)$ \\
\hline Pre ecclampsia-ecclampsia & $53(23.5 \%)$ \\
\hline IUFD & $16(7.1 \%)$ \\
\hline PPH & $4(1.7 \%)$ \\
\hline ICU admission & $4(1.7 \%)$ \\
\hline Cardiac failure & $2(0.8 \%)$ \\
\hline Maternal mortality & $1(0.4 \%)$ \\
\hline
\end{tabular}

Majority of the patients had a vaginal delivery. Of 225 women 99 (44\%) patients presented with pre-term labour, $56(24.8 \%)$ patients had intrauterine growth restriction, $53(23.5 \%)$ developed pre-ecclampsia, $16(7.1 \%)$ had fetal demise at the time of presentation, $4(1.7 \%)$ patients needed Intensive care and $1(0.4 \%)$ patient died of cardiac failure. 48 (21.3\%) new-borns needed NICU care.

Table 4: Neonatal complications.

\begin{tabular}{|lc|}
\hline Prematurity & $99(44 \%)$ \\
\hline IUGR & $56(24.8 \%)$ \\
\hline NICU admission & $48(21.3 \%)$ \\
\hline Neonatal death & $26(11.5 \%)$ \\
\hline
\end{tabular}

\section{DISCUSSION}

Anaemia in pregnancy is a major health problem in rural part of India due to various reasons like illiteracy, poverty, lack of awareness about the need for regular antenatal care and presence of superadded infections. Anaemia in pregnancy is a risk factor for preterm labour, intrauterine growth restriction, cardiac failure puerperal sepsis, sub-involution and failure of lactation. ${ }^{20}$ Severe anemia in pregnancy has a significant impact on maternal and perinatal outcome. Severity of anemia is an independent risk factor for LBW, pre-eclampsia. ${ }^{21-23} \mathrm{In}$ this study the prevalence of severe anaemia was $5.6 \%$ which is comparable with the study by Singhal et al (5.7\%), Vemulapalli and Rao reported a prevalence of $(6.28 \%)$ whereas study by Kumar et al observed a very low prevalence of $0.6 \%$ and study by Ahmed et all observed a high prevalence of $18 \%$. The prevalence of anemia of $45.7 \%$ was observed in the under 24 years age group which is comparable with the study by Sharma et al $(38 \%)$ whereas in a study by Kaul et al in Kashmir the prevalence of anemia of $93.67 \%$. Early age at marriage and poor iron stores contributes to high prevalence in this age group. The prevalence of severe anaemia was higher in unbooked patients which is observed in studies conducted by other authors as well. A prevalence of 21.3 $\%$ was observed in booked patients which could be due to non- compliance with iron therapy and lack of frequent haemoglobin estimation. Pre-term labour was more common in this study followed by IUGR and Preecclampsia. Results of this study correlate well with study by Devi BN and et al. ${ }^{24}$
To conclude in present study severe anemia was more prevalent in under 24 year age group, unbooked patients and multiparous pregnant females. Pre-maturity and LBW was the major maternal complication. Limitation of this study was failure to identify pregnant women with Vitamin B12 and folate deficiency, comparison of maternal and perinatal outcome in pregnant women with mild to moderate anemia.

\section{CONCLUSION}

Anaemia in pregnancy is still a tragic reality in rural areas. A high prevalence in developing countries is an indicator that a more aggressive approach is warranted at all levels of healthcare in managing this problem. Severe anaemia in pregnancy imparts more risk to the pregnant mother and the fetus in utero. Even a minor blood loss is devastating for such patients. Hence, awareness and education on early antenatal booking, regular iron intake and continuous antenatal care be the goal in tackling anaemia in pregnancy. Active participation of ASHA workers at grass root level should also be stressed.

\section{Funding: No funding sources}

Conflict of interest: None declared

Ethical approval: The study was approved by the Institutional Ethics Committee

\section{REFERENCES}

1. Baig-Ansari N, Badruddin SH, Karmaliani R, Harris $\mathrm{H}$, Jehan I, Pasha $\mathrm{O}$ et al Anemia prevalence and risk factors in pregnant women in an urban area of Pakistan. Food Nutr Bull. 2008 Jun;29(2):132-9.

2. Tolentino K, Friedman JF. An update on anemia in less developed countries. Am J Trop Med Hyg. 2007;77:44-51.

3. Cyril C. Dim, Hyacinth E. Onah. The prevalence of anemia among pregnant women at booking in Enugu, South Eastern Nigeria. Med Gen Med. 2007;9(3):11.

4. Kalaivani K. Prevalence and consequences of anaemia in pregnancy. Indian $\mathrm{J}$ Med Res. 2009;130:627-33.

5. Mangla M, Singla D. Prevalence of anaemia among pregnant women in rural India: a longitudinal observational study. Int $\mathrm{J}$ Reprod Contracept Obstet Gynecol. 2016;5:3500-5.

6. Sharma JB, Shankar M. Anemia in Pregnancy. JIMSA. 2010;23(4)

7. Kaur K. Anaemia 'a silent killer' among women in India: Present scenario. Euro J Zool Res. 2014;3(1):32-6.

8. Abiselvi A, Gopalakrishnan S, Umadevi R, Rama R. Anaemia among pregnant women in a rural area of Kancheepuram district, Tamil Nadu. Int J Community Med Public Health. 2017;4:2400-5.

9. Gupta SK, Agarwal SS, Kaushal R, Jain A ,Gupta VK, Khare N. Prevalence of rural population living in and around of rural health and training center, 
Ratua Village of Madhya Pradesh. Muller J Med Sci Res. 2014;5:15-8.

10. Toteja GS, Singh P, Dhillon BS, Saxena BN, Ahmed FU, Singh RP, Prakash B, Vijayaraghavan K, Singh Y, Rauf A, Sarma UC. Prevalence of anemia among pregnant women and adolescent girls in 16 districts of India. Food Nutr Bull. 2006 Dec;27(4):311-5.

11. Gautam VP, Bansal Y, Taneja DK, Saha R. Prevalence of anaemia amongst pregnant women and its socio-demographic associates in a rural area of Delhi. Ind J Com Med. 2002;27(4):157-60.

12. Virender PG, Yogesh B, Taneja DK, Renuka S. Prevalence of anemia amongst pregnant women and its socio-demographic associates in a rural area of Delhi. Indian J Comm Medicine. 2002;27:157-60.

13. Bisoi S, Haldar D, Majumdar T, Bhattacharya N, Sarkar G, Ray S. Correlates of anemia among pregnant women in a rural area of West Bengal. J Fam Welfare. 2011;57(1):72-8.

14. Ghimire RH, Ghimire S. Maternal and fetal outcome following severe anaemia in pregnancy: results from Nobel Medical College Teaching Hospital, Biratnagar, Nepal. J Nobel Med Coll. 2013;2(1):226.

15. Brabin BJ, Hakimi M, Pelletier D. An analysis of anemia and pregnancy-related maternal mortality. J Nutrition. 2001;131:604-14.

16. Ali AA, Rayis DA, Abdallah TM, Elbashir MI, Adam I. Severe anaemia is associated with a higher risk for preeclampsia and poor perinatal outcomes in Kassala hospital, eastern Sudan. BMC Res Notes. 2011;4:311.

17. VanderJagt DJ, Brock HS, Melah GS, El-Nafaty AU, Crossey MJ, Glew RH. Nutritional factors associated with anaemia in pregnant women in northern Nigeria. J Health Popul Nutr. 2007 Mar;25(1):75-8.

18. Van den Broek NR, Letsky EA. Etiology of anemia in pregnancy in south Malawi. Am J Clin Nutr. 2000;72:247S-56S.

19. Ghimire N, Pandey N. Knowledge and practice of mother regarding the prevention of anaemia during pregnancy, in teaching hospital Kathmandu. J Chitwan Med Coll. 2013;3(5):14-7.

20. Sabina S, Iftequar S, Zaheer Z, Khan M, Khan S. An overview of anemia in pregnancy. JIPBS. 2015;2(2):144-51.

21. Karaoglu L, Pehlivan E, Egri M, Deprem C, Gunes $\mathrm{G}$, Genc MF et al. The prevalence of nutritional anemia in pregnancy in an east Anatolian province, Turkey. BMC Public Health. 2010 Dec;10(1):329.

22. Munasinghe $\mathrm{S}$. Anaemia in pregnancy in Malawi-a review. Malawi Med J. 2006;18(4):160-75.

23. Geelhoed D, Agadzi F, Visser L, Ablordeppey E, Asare K, O'rourke $\mathrm{P}$ et al. Maternal and fetal outcome after severe anemia in pregnancy in rural Ghana. Acta Obstet Gynecol Scand. 2006;85(1):4955.

24. Nirmala Devi B, Varalaxmi B, Jyothirmayi T, Lahari $\mathrm{N}$. Maternal outcome in pregnancy with severe anaemia: Prospective study in a tertiary care hospital in Andhra Pradesh. JDMS. 2015;14(4):06-10.

Cite this article as: Sapre SA, Raithatha NS, Bhattacharjee RS. Severe anemia in late pregnancy: a retrospective study at a tertiary care rural medical college in Gujarat, India. Int J Reprod Contracept Obstet Gynecol 2018;7:1112-5. 